\title{
A EFICÁCIA DA CARTA DE DIREITOS FUNDAMENTAIS DA UNIÃO EUROPEIA À LUZ DA JURISPRUDÊNCIA MAIS RECENTE DO TRIBUNAL DE JUSTIÇA1
}

\section{THE EFFECTIVENESS OF THE EU CHARTER OF FUNDAMENTAL RIGHTS IN VIEW OF RECENT CASES OF THE EUROEPAN COURT OF JUSTICE}

Augusto Aguilar Calahorro²

\begin{abstract}
Resumo: $O$ artigo analisa a eficácia da Carta de Direitos Fundamentais da União Europeia, sua verdadeira normatividade e sua iusfundamentalidad. Partindo de uma distinção entre a eficácia dos direitos incorporados em tratados internacionais e a natureza dos tratados da União Europeia, concluiu-se que os direitos da Carta da União exigiram que seu desenvolvimento normativo fosse invocado pelos cidadãos, o que gerou uma espécie de eficácia mediada, contradizendo sua natureza supranacional. No entanto, a jurisprudência dos últimos anos (Bauer e Engenberger) está alterando essas conclusões, permitindo a efetividade direta de direitos sociais em âmbito supranacional.
\end{abstract}

Palavras-chave: Eficácia dos direitos. Natureza supranacional da União Europeia. Eficácia. Tratados internacionais.

\begin{abstract}
This paper aims to show how the effectiveness of the Charter of fundamental rights of the European Union, starting from a distinction between the effectiveness of the rights included in international treaties and the nature of the treaties of the European Union, ends by stating that the rights of the Charter of the Union have required their normative development to be invoked by citizens, which generates a kind of drittwirkung effectiveness of them, which contradicts their supranational nature. However, the jurisprudence of recent years (Bauer and Engenberger) is altering these conclusions, allowing the direct effect of social rights in the supranational sphere.
\end{abstract}

Keywords: Effectiveness of rights. Supranational nature of the European Union. Effectiveness. International treaties.

Recebido em 6 de fevereiro de 2020

Aceito em 23 de abril de 2020

\section{Introdução}

A eficácia da Carta de Direitos Fundamentais da União Europeia (CDFUE) está no cerne do desenvolvimento do constitucionalismo multinível e é um espelho da sua crise. Todo discurso sobre constitucionalismo, por mais que ocupe muitos níveis, deve seguir centrado nas pessoas, na

\footnotetext{
Traduzido por Michel Ferrari Borges dos Santos; Doutorando em Direitos Fundamentais pelo Programa de Pós-graduação em Direito da Universidade do Oeste de Santa Catarina (Unoesc/Chapecó); Advogado; https://orcid.org/0000-0002-98742007; michelfbsadv@gmail.com

Milena Veloso de Linhares; Mestre em Direitos Fundamentais pelo Programa de Pós-graduação em Direito da Universidade do Oeste de Santa Catarina (Unoesc/Chapecó); Professora na Faculdade de Concórdia (FACC); Advogada e Juíza leiga no Tribunal de Justiça do Estado do Rio Grande do Sul; milenalinhares94@gmail.com

Robison Tramontina; Doutor em Filosofia pela Pontifícia Universidade Católica do Rio Grande do Sul (PUC/RS); Coordenador do Programa de Pós-graduação em Direito na Universidade do Oeste de Santa Catarina (Unoesc/Chapecó); https://orcid.org/0000-0002-1852-4983; robison.tramontina@unoesc.edu.br

2 Doutor em Direito pela Universidade de Granada; Professor de Direito Constitucional na Universidade de Granada, Plaza de la Universidad, s/n, 18001, Granada, Espanha; https://orcid.org/0000-0001-8239-6712; augustoaguilar@ugr.es
} 
capacidade de emancipação e proteção dos seres humanos (a dignidade humana como "premissa antropológica" do Estado constitucional (HÄBERLE, 2009, p. 413 ss.) que dispensam os sistemas jurídicos constitucionais.

Um discurso jurídico sobre a eficácia da CDFUE deve, portanto, ter como finalidade revelar a verdadeira capacidade real e efetiva desta para garantir os direitos que prescrevem às pessoas.

Nesse contexto, conforme recentemente observou o professor Cruz Villalón (2017, p. 101 ss.), estamos diante de "uma série de obstáculos ou de um triplo salto mortal", pois a CDFUE tem, inevitavelmente, uma eficácia dinâmica que deve lidar com os limites de seu passado internacional e as expectativas de seu presente constitucional.

Por isso, é necessário que repensemos questões clássicas de Direito internacional público e atuais de Direito constitucional europeu para compreender o processo de evolução em torno da eficácia da Carta europeia.

\section{Os cidadãos e o direito europeu}

Se algo tem revolucionado o processo de integração europeia numa perspectiva jurídica, é a posição concedida aos cidadãos na esfera internacional, ou seja, os cidadãos são sujeitos de Direito supranacional como os poderes públicos e os Estados. ${ }^{3}$ É revolucionário, pois não podemos esquecer que a origem do ordenamento europeu é o Direito internacional.

Segundo a clássica definição do Direito internacional público, deve-se entender por subjetividade, no âmbito do direito internacional, a idoneidade para ser "titular de relações jurídicas subjetivas atribuídas pelo Direito internacional." ${ }^{4}$ Durante todo o século XIX e até meados do século $\mathrm{XX}$, a doutrina internacionalista se esforçou para determinar a quem eram dirigidas as normas de Direito internacional. A preocupação era compreender quem eram os titulares de tais direitos e deveres. A conclusão predominante foi de que os indivíduos entravam na esfera jurídica internacional não como sujeitos de direitos, mas sim como meros objetos. ${ }^{5}$

Essa tese foi baseada em três argumentos (MASTROMARTINO, 2010, p. 416).

Em primeiro lugar, o Direito internacional era um complexo de normas destinado a regular as relações entre os Estados, portanto, eles eram os únicos destinatários.

Em segundo lugar, a sociedade internacional se fundava nas relações entre entes autônomos, independentes e formalmente iguais (Tratado de Westfalia), razão pela qual se devia excluir os indivíduos por estarem subordinados aos Estados - os verdadeiros sujeitos (MODUGNO,

\footnotetext{
3 Acórdãos do "Tribunal de Justiça" (SSTJ) de 5 de fevereiro de 1963 Van Gend en Loss, C-26/62; e de 15 de julho de 1964, Costa contra ENEL, C-6/64.

4 Veja-se Mastromartino (2010, p. 416). Também Arangio-Ruiz (1951, p. 9): "[p]er 'soggettività' in ambito internazionale la dottrina conviene di intendere l'idoneità di un ente ad essere reso dal diritto internazionale titolare di situazioni giuridiche soggettive."

5 "Come non è possibile determinare a priori il dominio personale di validità del diritto interno, così è impossibile determinare a priori la cerchia dei soggetti del diritto internazionale. Il giurista [...] ha il compito di vedere volta a volta, sulla base delle singole disposizioni vigenti, quali ne sono $i$ destinatari." (QUADRI, 1949, p. 60 apud MASTROMARTINO, 2010, p. 416).
} 
1985, p. 253, 255; ROMANO, 1939, p. 60). Era através dos ordenamentos dos Estados e de seus poderes públicos que se concedia eficácia aos direitos e deveres dos cidadãos prescritos nas cartas e convênios internacionais.

E em terceiro lugar, o argumento de que "os indivíduos não possuem, por iniciativa própria, os meios necessários para fazer cumprir o Direito internacional a seu favor." (MASTROMARTINO, 2010, p. 416).

Esses argumentos incorporam a "tese negativa" do Direito internacional, que nega aos cidadãos a subjetividade desse ramo do Direito. Assim, não basta ser destinatário de direitos ou obrigações de normas internacionais, mas é necessário ter a capacidade de exigir sua aplicação em favor de pretensões subjetivas e, sobretudo, que esta capacidade esteja estabelecida no próprio ordenamento internacional, e não pelo ordenamento estatal. ${ }^{6}$

Para os internacionalistas, as capacidades dos cidadãos para atuar em âmbito internacional (perante um tribunal internacional ou como destinatários das normas internacionais) eram apenas um reflexo mediato das obrigações dos Estados signatários.

Como observou Quadri, quando os tratados internacionais falam de direitos e deveres dos particulares, não fazem outra coisa que não seja obrigar os Estados a atribuir e, respectivamente, impor aos indivíduos, mediante seu ordenamento jurídico interno, tais direitos e deveres. Assim, a fonte desses direitos se encontraria no direito interno dos Estados. ${ }^{7}$

Também para teoria do Direito, para Kelsen, as proposições normativas internacionais nas quais se expressavam direitos ou deveres dos indivíduos, expressavam a simples atribuição indireta (ou seja, através do ordenamento jurídico dos Estados) de deveres e direitos (KELSEN, 2005, p. 178 ss.).

Para esta doutrina, os verdadeiros titulares das relações jurídicas de normas internacionais seriam "não aos entes a quem essas normas são dirigidas, mas sim, exclusivamente, aos entes que também foram dotadas, diretamente pelo próprio sistema jurídico internacional, de um poder de ação funcional de exercício dos direitos que lhe são atribuídos." (MASTROMARTINO, 2010, p. 428). "Diretamente" é a palavra-chave.

\footnotetext{
6 Veja-se Diez de Velasco (2002, p. 250-251). Também Arangio-Ruiz (1951). Cassese (1971, p. 185-186) distinguia sujeitos jurídicos de soggetti formulari: "Perché un ente possa essere definito titolare di situazioni giuridiche soggettive, occorre non solo che tali situazioni risultino garantite, ma anche che i meccanismi idonei ad assicurare la loro concreta attuazione non dipendano solo ed esclusivamente da altri enti, ma possano essere messi in moto dallo stesso ente interessato, o quantomeno abbiano un carattere tale da non abbisognare di essere promossi da altri soggetti"; "Un ente può essere considerato destinatario di norme di un certo ordinamento solo se le garanzie di tali norme sono concretamente apprestate dall'ordinamento stesso."

7 Conforme Quadri (1935, p. 58 apud MASTROMARTINO, 2010, p. 20), no texto literal: "Quando i trattati internazionali parlano di diritti, doveri, ecc. dei singoli, non fanno altro che obbligare gli Stati ad attribuire e rispettivamente imporre agli individui, mediante i loro ordinamenti giuridici interni, i diritti e i doveri di cui è parola. Cosicché la fonte di questi va sempre ricercata nel diritto interno degli Stati $[\ldots] "$
} 
Autores como Cassese $e^{8}$ ou Sperduti consideraram que essa doutrina do Direito internacional se inspirou em uma concepção realista baseada no princípio da efetividade. ${ }^{9}$ Essa postura é resumida pela doutrina anglo-saxônica como: "Legal action is the index of juristic personality." (O'CONNELL, 1970, p. 81 apud MASTROMARTINO, 2010, p. 429).

Essa postura negativa, do começo do século passado, foi pouco a pouco superada pela internacionalização dos direitos humanos, que vem acontecendo desde o fim da II Guerra Mundial. Desde os julgamentos de Nuremberg (e do reconhecimento da responsabilidade penal internacional dos indivíduos) até o Estatuto da Corte Penal Internacional, passando obviamente pela clareza da Declaração de Direitos Humanos das Nações Unidas até chegar ao revolucionário protocolo n. 11 do Convênio Europeu de Direitos Humanos. Esses marcos jurídicos históricos mudaram, sem dúvida, a perspectiva do cidadão em relação ao Direito internacional e, particularmente, a natureza dos direitos humanos que os convênios e tratados lhes concedem. Ao mesmo tempo, a Constituição normativa e pluralista foi imposta na Europa, centralizada na premissa cultural antropológica da dignidade humana.

No entanto, as raízes do discurso pesam ainda sobre o desenvolvimento progressivo do sistema multinível de proteção de direitos, levantando questões que transcendem o âmbito iuspublicista e transcorrem em paralelo à ciência constitucional, até colidirem no processo de integração europeia.

Das doutrinas negativas originais sobre a subjetividade do Direito extraestatal, interessam duas ideias neste momento: as consequências de se vincular a ação processual com o direito subjetivo; a ideia de que os direitos e deveres internacionais têm uma eficácia mediata desenvolvida através dos poderes públicos estatais - Drittwirkung-.

\subsection{Os direitos e suas garantias no âmbito internacional}

Por um lado, como acabamos de dizer, os que negavam que os cidadãos fossem considerados sujeitos do Direito internacional por sua falta de capacidade para forçar a aplicação desse direito em favor de pretensões subjetivas, içaram uma concepção "realista", baseada no princípio da efetividade. Resumindo, poderíamos dizer que se o Direito internacional expressa direitos para os cidadãos e

\footnotetext{
8 "Dire che un ente è titolare di un diritto soggettivo o di una pretesa quando esso risulta radicalmente privo di qualsiasi mezzo per garantire effettivamente l'attuazione di tali asserite situazioni giuridiche, ed invece di siffatta attuazione dispone a sua assoluta discrezionalità un altro ente (lo Stato nazionale), significa assegnare un valore puramente nominalistico al concetto di soggettività"; "Perché un ente possa essere definito titolare di situazioni giuridiche soggettive, occorre non solo che tali situazioni risultino garantite, ma anche che i meccanismi idonei ad assicurare la loro concreta attuazione non dipendano solo ed esclusivamente da altri enti, ma possano essere messi in moto dallo stesso ente interessato, o quantomeno abbiano un carattere tale da non abbisognare di essere promossi da altri soggetti"; "Un ente può essere considerato destinatario di norme di un certo ordinamento solo se le garanzie di tali norme sono concretamente apprestate dall'ordinamento stesso." (CASSESE, 1971, p. 186-189).

9 Sperduti (1950, p. 11-16) concebe "il diritto internazionale come ordinamento che realisticamente si adegua alle proprie basi sociali [...] e assume come direttiva di coordinare il proprio sviluppo evolutivo all'evoluzione di dette basi, ossia all'evoluzione della struttura stessa della società Internazionale."
} 
que eles não possuem capacidade para faze-los valer perante os demais sujeitos, então não podem ser chamados de verdadeiros direitos subjetivos, sob pena de tornar o Direito internacional um mecanismo vazio para a resolução de conflitos interpessoais. ${ }^{10}$

A vinculação entre a subjetividade jurídica no Direito internacional e a capacidade de exercer uma ação processual para garantir pretensões jurídicas baseadas em direitos subjetivos, levantou, e ainda suscita, sérias discussões científicas. Como observa Mastromartino (2010, p. 431):

fazer a atribuição da subjetividade de um ente depender do reconhecimento da sua capacidade de atuação, significa confundir a causa, a subjetividade, com seus efeitos. Essa confusão - a sobreposição da capacidade de jouissance com a capacité d'exercice - traz a origem do nexo que a doutrina internacionalista, de impressão realista, supõe entre os conceitos de 'sujeito jurídico' e de 'direito subjetivo' e que termina por esvaziar os direitos, atribuídos aos indivíduos pelo direito internacional, devido à sua natureza de direitos fracos e não garantidos.

A partir desse entendimento se critica a posição positivista sustentada pelo próprio Kelsen (2005, p. 178 ss.), para quem 'direitos subjetivos' seriam aquelas situações jurídicas cuja garantia consiste em outra situação jurídica destinada a tornar o sujeito titular da primeira situação jurídica - capaz de fazer valer suas próprias prerrogativas frente a outro sujeito - imputando-lhe obrigações e proibições correspondentes.

Tal postura também foi criticada por Ferrajoli (1999). Para ele, equiparar os direitos com suas garantias significa negar, entre outras consequências, o importantíssimo avanço dos direitos sociais e de sua internacionalização.

Essa crítica, numa perspectiva própria do Direito constitucional europeu, foi expressa brilhantemente pelo juiz Pescatore (1996, p. 7-32) nas primeiras décadas da construção europeia:

[...] temos na reserva um ditado que diz: Ubi ius ibi remedium [que...] reflete o pensamento jurídico mais moderno, segundo o qual, o fenômeno fundamental é o direito material, enquanto os trâmites processuais possuem apenas um caráter instrumental relacionado à substância do direito - direito material. É a diferença, segundo a sistemática alemã, $[\ldots]$ entre $[\ldots]$ o pensamento em categorias de direito material contra o pensamento em categorias de soluções processuais. A ideia é que a função do processo judicial é consolidar, e não condicionar a vigência do direito material. Devemos tomar cuidado neste passo, para que nosso ditado não se inverta em um: Ubi remedium ibi ius, o que caracteriza a atitude fundamental da Common law, onde aparentemente a existência de um direito subjetivo decorre da existência do procedimento, e não o inverso.

Certamente, deve-se considerar que existem importantes diferenças de resultado na fundamentação dos direitos caso se utilize de um pensamento baseado em categorias de direito material ou um pensamento baseado em remédios processuais. Que no sistema multinível se impôs a ideia de que existe um direito material com conteúdos mínimos comuns, e que eles se enriquecem

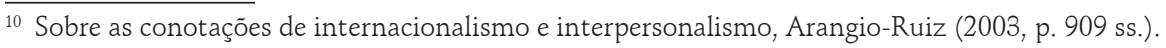


através dos distintos procedimentos de garantia que podem desenvolver-se nos diferentes níveis - sem que o direito subjetivo desapareça porque os remédios são menores no plano internacional e maiores no constitucional, mas, ao contrário, o direito substantivo pode pouco a pouco desenvolver-se e se enriquecer pelos diferentes remédios processuais. Mas, interessa destacar, em nível internacional, que a impossibilidade de invocar direitos subjetivos internacionais perante a jurisdição resulta na perda de eficácia ou effet utile de qualquer compromisso internacional. ${ }^{11}$

Assim sendo, deve-se entender (como fez o Tribunal de Justiça da EU - TJUE - em interpretação dos Tratados Fundacionais da União) que a forma mais efetiva de assegurar a vinculação dos poderes públicos nacionais aos compromissos internacionais é permitir, a cada um dos cidadãos, que baseie suas pretensões subjetivas em direitos e deveres internacionais e invoque suas normas perante a jurisdição. ${ }^{12}$ Os procedimentos de invocação do Direito têm dois resultados diretos sobre a constitucionalização dos sistemas jurídicos e sua estrutura.

Por um lado, com a possibilidade de os cidadãos invocarem pretensões baseadas em disposições internacionais, garante-se o cumprimento das obrigações dos Estados derivadas das convenções e tratados - é a natureza vinculante dos compromissos internacionais.

Por outro lado, os procedimentos de invocação do Direito pelos cidadãos perante a jurisdição abrem uma via jurídica que pode contribuir para a legitimação do ordenamento internacional. Refirome ao papel dos cidadãos no desenvolvimento da "infraestrutura social" (MASTROMARTINO, 2010, p. 431) e no êxito do Direito, destinado a resolver conflitos provocados pelas relações globais (a nível europeu). Parafraseando Lenaerts, podemos afirmar que qualquer ordenamento que parta de normas legais que prometem uma realidade que os cidadãos não podem desfrutar, acabará perdendo, na prática, toda a credibilidade, por isso "uma mais efetiva e orientada aplicação do Direito [e dos direitos] pode ajudar a restaurar a fé em sua própria razão de ser. Uma abordagem mais uniforme na invocação do Direito pode contribuir para fortalecer sua legitimidade." (LENAERTS; CORTHAUT, 2006, p. 287 ss.).

Por essa razão, é compreensível a postura realista, que embasa a efetividade do Direito internacional na negação do cidadão como sujeito do Direito internacional. Ou o cidadão pode desfrutar efetivamente dos direitos previstos pelas normas internacionais ou não é sujeito de nada.

Para Bogdandy (2000, p. 304-305) "a função primeira da ciência jurídica como uma ciência prática, [...] consiste no 'cuidado' de uma importante 'infraestrutura' social, principalmente na produção e na garantia da transparência e coerência do Direito."

\footnotetext{
${ }_{11}$ Assinala-se que o princípio do efeito útil dos tratados internacionais tem sido muito importante para que o TJUE estenda a eficácia direta do Direito da União para determinadas qualidades diretivas, com base nos compromissos internacionais assumidos pelos Estados. Ver como exemplo os Acórdãos do Tribunal de Justiça de 1970 e 1974, respectivamente dos Processos 9/70, Grad, e 41/74, Van Duyn.

${ }^{12}$ Na jurisprudência, Van Gend en Loss y Costa c. Enel. Ver nota 2. Na doutrina, remete-se essencialmente à obra de Ward (2000, p. 158).
} 
Em outras palavras, essa ideia realista do Direito internacional, naquilo que nos interessa, não somente nega a subjetividade dos indivíduos e dos cidadãos, por serem destinatários de direitos que não têm capacidade de pleiteá-los por si mesmos (vinculando a ideia de direitos subjetivos com suas garantias); mas também vincula a própria ideia de Direito (com letras maiúsculas) ao verdadeiro gozo dos direitos pelos cidadãos. ${ }^{13}$ E essa é uma lição necessária que devemos levar em conta, pois o Direito é um mecanismo para resolução de conflitos sociais e se esse mecanismo perde sua capacidade para resolver esses conflitos, os cidadãos recorrem a vias extrajudiciais, normalmente violentas, que resultam na perda da utilidade e da eficácia do Direito.

Por esta razão, deve-se ser cauteloso ao invocar uma disposição legal como um direito ou de se afirmar que os cidadãos são titulares de direitos subjetivos quando não se tem mecanismos para garanti-los. Os remédios processuais não podem ser tratados de forma meramente instrumental em relação aos direitos materiais, pois para a válida existência do Direito, eles têm um componente legitimador e reforçam seu caráter vinculante.

\subsection{A eficácia mediata dos direitos}

A partir da doutrina iuspublicista sobre a subjetividade, podemos destacar um segundo elemento que converge com a teoria constitucional. Os sujeitos de Direito internacional devem ser dotados "diretamente" pelo próprio sistema jurídico internacional de um poder de ação para exercer os direitos que lhes são atribuídos (MASTROMARTINO, 2010, p. 428). Por essa razão, os cidadãos não se consideram sujeitos de Direito, pois são os Estados que impõem aos indivíduos, mediante seu ordenamento interno, tais direitos e deveres. A fonte de direito dos cidadãos se torna o ordenamento interno do Estado e não o Direito internacional, que expressa apenas uma atribuição indireta (ou seja, feita através do ordenamento jurídico dos Estados) de deveres e direitos.

Esse caráter mediato, que faz com o que cidadãos percam a subjetividade na esfera dos direitos internacionais, é comparável (mutatis mutandi) com a dogmática constitucional sobre a eficácia horizontal dos direitos fundamentais entre particulares ou drittwirkung. ${ }^{14}$ Uma categoria que cada vez com mais intensidade se movimentou para o âmbito da proteção internacional dos direitos. $^{15}$

\footnotetext{
${ }^{13}$ Isso fundamenta o Direito internacional no princípio da efetividade, pois, como observa Sperduti (1950, p. 11, 16), o Direito internacional se concebe como um ordenamento que "realisticamente" se adapta às bases sociais e assume como diretiva coordenar seu próprio desenvolvimento com o desenvolvimento dessas bases, ou seja, com a evolução da própria estrutura da sociedade internacional.

${ }^{14}$ Para toda definição da STC 53/1985, que segue substancialmente o decidido no Caso Lüth, do Tribunal Constitucional Federal Alemão (1958): os direitos fundamentais são direitos de defesa do cidadão contra o Estado; no entanto, incorpora-se também uma ordem de valores objetiva, válida para todas as esferas, que levam à obrigação dos poderes públicos de garantir direitos nas relações horizontais, seja através do legislador, seja através do aplicador do Direito. E sua versão da State Action norte-americana, no caso Adickes v. Kress (1970), em que se concede eficácia horizontal aos direitos constitucionais, quando o particular aparentemente age de maneira lícita de acordo com um costume ou uso do Estado ou com o envolvimento de um funcionário (convalidação de um ato por um juiz).

15 Ver, por exemplo, Alfaro (2019) e Beladíez (2017).
} 
$\mathrm{Na}$ esfera internacional europeia, esta tem sido a abordagem do Tribunal Europeu de Direitos Humanos, ${ }^{16}$ e também o da Corte Interamericana. ${ }^{17}$

Destacamos, especialmente, a utilização dessa doutrina no progressivo desenvolvimento da teoria dos direitos no âmbito da União europeia. Por exemplo, como afirmou Cruz Villalón (2013), nas alegações finais do caso mas:

o problema do que é frequentemente chamado de Drittwirkung, [...] consiste em compreender que a obrigação dos particulares em respeitar os direitos e liberdades dos outros vem normalmente imposta, de forma imediata e direta, pelo próprio poder público. A partir dessa perspectiva, a ideia de sujeição dos particulares aos direitos fundamentais se traduz frequentemente no "dever de proteção" dos direitos por parte do poder público [...]. E a noção de eficácia horizontal se traduz em um aumento marcante da presença do interprete jurídico dos direitos fundamentais na gestão das relações jurídico-privadas. ${ }^{18}$

Da mesma forma, o Advogado-geral Maduro, nas suas alegações finais, no caso Viking, adotou essa posição na esfera das liberdades econômicas, "uma maneira comum de conferir força normativa aos direitos constitucionais nas relações horizontais é considera-los vinculantes para o juiz na resolução de casos concretos entre particulares. Seja ao interpretar uma cláusula contratual, ao se pronunciar em um pedido de indenização ou de medidas cautelares, o órgão judicial, como órgão do Estado, está obrigado a proferir uma sentença que respeite os direitos constitucionais das partes. A delimitação dos direitos individuais assim procedida é conhecida como mittelbare drittwirkung ou efeito horizontal indireto. O resultado é que as normas constitucionais dirigidas ao Estado se transformam em normas jurídicas que se aplicam entre os particulares, ilustrando que "o estado é o terceiro que em todo litígio entre particulares" e "o é através da própria lei e do juiz que a aplica." (MADURO, 2007). ${ }^{19}$

Como sabemos, a nível interno, esta eficácia mediata se dá especialmente nos casos de direitos de conteúdo prestacional, econômicos e sociais, que requerem, por um lado, o interpositio legislatoris para determinar as condições jurídicas de efetividade do direito e, por outro lado, de um

\footnotetext{
${ }^{16}$ É a conhecida teoria das "obrigações positivas do Estado". Acórdãos do Tribunal Europeu de Direitos Humanos Airey c. Irlanda, de 9 de outubro de 1979; Lopez Ostra c. España, de 9 de dezembro de 1994; e Ilascu y otros c. Moldavia y Rusia, de 8 de julho de 2004.

17 Embora em âmbito internacional/interamericano tenha se recorrido aos princípios de Ius Cogens para aprofundar a mesma ideia, indiretamente o Estado é responsabilizado pela falta de proteção dos direitos no âmbito das relações de trabalho. Veja-se "consulta de opinião" solicitada pelo México à CIDH 18/03 sobre a condição jurídica dos imigrantes. 2002 STS EE.UU Hoffman Plastic Compounds v. National Labor Relations Board. A CIDH estabelece que a Carta interamericana dispõe de normas de ius cogens. Em uma relação de trabalho regida pelo direito privado, deve-se levar em conta que existe uma obrigação de respeito aos direitos humanos nessa relação (Consulta de opinião n. 18/03, parágrafo 140). A obrigação imposta pelo respeito e garantia dos direitos humanos frente a terceiros se baseia também na concepção de que os Estados determinam seu próprio ordenamento jurídico, que regula as relações entre particulares e, portanto, o direito privado, devendo também zelar para que nas relações privadas entre particulares os direitos humanos sejam respeitados, caso contrário o estado pode ser responsabilizado pela violação desses direitos (Consulta de opinião n. 18, parágrafo 147).

${ }^{18}$ Conclusões do Advogado Geral Cruz Villalón, apresentadas em 18 de julho de 2013, Processo C176/12, Association de Médiation Sociale (AMS), pontos 36 e 37.

${ }^{19}$ Conclusões do Advogado-geral Maduro, apresentadas em 23 maio de 2007, Processo C-438/05, Viking Line.
} 
procedimento jurisdicional para sua invocação. A ideia da sujeição dos particulares a alguns direitos subjetivos, especialmente os de conteúdo social e económico, se traduz frequentemente no "dever de proteção" dos direitos por parte do poder público e na ineficácia horizontal deles.

Com essa breve exposição, destacamos duas ideias. Em primeiro lugar, há um paralelismo inicial entre a doutrina iuspublicista, que nega subjetividade aos cidadãos por não estarem dotados diretamente, pelo sistema jurídico internacional, de um poder de ação para exercer os direitos que a eles são atribuídos (ARANGIO-RUIZ, ${ }^{1951)} \mathrm{com}$ a doutrina constitucional que entende pela necessidade de interpositio legislatoris e mediação jurisdicional para conceder eficácia horizontal aos direitos constitucionais, especialmente os de conteúdo econômico e social. Isso permitiria transportar questionamentos propriamente constitucionais para a esfera internacional dos direitos e abrir um campo interessante de estudo. Por exemplo, a questão da eficácia dos direitos internacionais nas relações horizontais. Esse campo de estudo foi explorado, ainda que com cautela, pelos advogados gerais do Tribunal de Justiça da União Europeia para resolver questões importantes sobre a natureza do ordenamento europeu. Por exemplo, no caso Viking acima citado, o Advogado-geral Maduro (2007) considerou que "em essência, não há nenhuma diferença" entre a delimitação dos respectivos âmbitos de proteção de direitos no efeito horizontal indireto ou no efeito horizontal direto, ainda que nessas conclusões o próprio autor argumenta que em alguns casos (como no caso Schmidberger ${ }^{20}$ ) o efeito indireto permite aos tribunais resolver o conflito sem ter que sopesar os direitos das partes que entram em conflito, ou seja, sem realizar a ponderação dos direitos envolvidos no caso concreto. Alinhar a doutrina iuspublicita da subjetividade com a doutrina constitucional do Drittwirkung, em um simples olhar, já levanta as deficiências dogmáticas no ordenamento internacional em torno das questões da ponderação de direitos e de seus limites.

Em segundo lugar, deve-se considerar que em um mundo economicamente globalizado, perdem eficácia os direitos que não podem ser manejados frente aos poderes econômicos, grandes empresas ou multinacionais, em relações entre particulares e, especialmente, na esfera jurídicoprivada das relações de trabalho ou de consumo. Nem um nem o outro seriam resolvidos através da interposição e mediação dos poderes públicos estatais, o que redunda em uma perda de efetividade ou legitimidade ou effet utile do Direito Internacional como mecanismo de resolução de conflitos.

\subsection{A Revolução Europeia}

Como dissemos ao início, se algo revolucionou o processo de integração europeia sob o ponto de vista jurídico, foi a posição concedida aos cidadãos na esfera internacional. Os cidadãos são sujeitos de Direito supranacional, da mesma forma que os poderes públicos e os Estados. Essa ideia revoluciona o sistema jurídico internacional, pois estabelece as bases de uma comunidade de Direito,

\footnotetext{
${ }^{20}$ Acórdão do Tribunal de Justiça de 12 de junho de 2003, Schmidberger, C-112/00.
} 
que é o que diferencia o âmbito internacional do âmbito supranacional, da eu. ${ }^{21}$ A aplicação do Rule of Law à esfera externa do Estado.

Os poderes públicos e os cidadãos estão vinculados ao Direito europeu, como fonte autônoma e com eficácia própria, e suas relações se regem por normas que se impõe a todos eles. ${ }^{22}$

A consideração da União Europeia como uma comunidade de Direito implicou a equiparação da força dos tratados constitutivos à mais elevada manifestação do Rule of Law em nível nacional, isto é, não somente como princípio de legalidade, mas também como princípio de constitucionalidade (DÍEZ-PICAZO, 2002).

Essa comunidade de direito é construída sobre dois princípios pretorianos elaborados pela jurisprudência do TJUE: a primazia do Direito europeu e sua eficácia direta. Estes princípios significam que os cidadãos podem invocar disposições europeias para fundamentar pretensões subjetivas perante o sistema jurídico dos Estados membros e que, em caso de contradição, deve prevalecer a norma europeia. ${ }^{23}$

Situar os cidadãos como sujeitos do Direito europeu e estabelecer um espaço supranacional regido pelo Rule of Law é o ponto de partida para a constitucionalização da União europeia, que distingue precisamente a natureza do ordenamento europeu do ordenamento internacional:

a) a natureza de sujeitos de Direito dos cidadãos, baseada na capacidade de requerer seus direitos, através de pretensões subjetivas, diretamente em disposições europeias, que podem ser invocadas perante a jurisdição. Dito de outro modo, a vinculação entre direitos subjetivos e sujeitos de direito, baseada em remédios processuais;

b) a autonomia do Direito europeu, que significa que a fonte de tais direitos subjetivos são os próprios tratados, que possuem uma eficácia específica e autônoma em relação aos poderes públicos estatais: eficácia direta e primária. A eficácia do Direito europeu

\footnotetext{
${ }^{21}$ Quanto à dimensão materialmente constitucional dos Tratados e a transformação da Rule of Law a nível supranacional, é clássica a referência ao acordão do Tribunal de Justiça, de 23 de abril e 1986, Parti écologiste "Les Verts", C-294/83, em que o TJUE explicita sua ideia de constitucionalização do ordenamento europeu através da interpretação dos tratados, declarando: "A Comunidade Econômica Europeia é uma Comunidade de Direito, na medida em que nem seus Estadomembros e nem suas instituições podem evitar o controle da conformidade de seus atos com a carta constitucional fundamental, que é o Tratado." E de forma definitiva no parecer do TJUE 1/91, de 14 de dezembro de 1991, sobre o acordo do Espaço Econômico Europeu: "Embora o Tratado CEE tenha sido celebrado em forma de convênio internacional, não deixa de ser a carta constitucional de uma Comunidade de Direito." Como observa Díez-Picazo (2002, p. 202): "a consideração da União Europeia como uma Comunidade de Direito significou igualar a força dos Tratados constitutivos à mais elevada manifestação do Rule of Law a nível nacional, ou seja, não somente como princípio de legalidade, mas também como princípio de constitucionalidade." De todos, remeto a De Witte (1999, p. 208). Sobre as implicações da Carta para a construção da comunidade supranacional do direito, veja-se Balaguer Callejón (2004) e Cámara Villar (2005).

22 Também pode ser destacada, como um dos primeiros reconhecimentos por um Tribunal Constitucional da natureza constitucional "em certo sentido" dos Tratados, a Portaria do Tribunal Constitucional Federal alemão BverfGE, 22, 293, EcuG-Verondnuger, de 18 de outubro de 1967, ordenação onde os efeitos de primazia e eficácia direta são reconhecidos, mas considerando que a atribuição de competência não é absoluta e pode haver limites para a eficácia do direito europeu no âmbito interno. O TCFA qualifica o Tratado CECA como a Carta Constitucional da Comunidade.

${ }^{23}$ Entre outros autores, recomenda-se a leitura de Aguilar Calahorro (2005).
} 
decorre de forma direta e autônoma dos próprios tratados, sem necessidade de mediação pelo Estado.

Se este é o ponto de partida da constitucionalização do Direito europeu, o atual ponto de desenvolvimento deveria ser a entrada em vigor da Carta dos Direitos Fundamentais da União Europeia, que constituiu a materialização dos postulados de um sistema constitucional baseado, até 2009, na construção jurisprudencial do TJUE. Mas, paradoxalmente, a eficácia da Carta pôs em questionamento a natureza da União, a ponto de assumir um verdadeiro passo atrás, em direção à reinternacionalização do processo de integração.

Até recentemente, poderia se afirmar que a Carta não atribuía diretamente direitos aos cidadãos e nem poderia ser diretamente invocada na maioria dos casos, mas requeria a mediação do legislador dos Estados - o que resultava em uma perda de sua efetividade nas relações entre particulares. Obviamente, essa afirmação parecia reverter a subjetividade dos cidadãos europeus até os postulados iuspublicistas, que comentamos até agora.

\section{A eficácia da Carta e suas dúvidas}

No processo de redação, positivação e posterior entrada em vigor da Carta no Tratado de Lisboa, em 2009, surgiram muitas dúvidas doutrinárias sobre sua verdadeira eficácia ${ }^{24}$. Essas dúvidas giram em torno do capítulo VII, as cláusulas horizontais. As disposições gerais expressam o âmbito de aplicação dos direitos, seu alcance e o nível de proteção, ou seja, sua verdadeira eficácia. E essa eficácia vem predeterminada pelo princípio da atribuição de competência.

Ao longo do Tratado de Lisboa e da própria Carta, repete-se como um mantra que ela não alarga o âmbito de aplicação do ordenamento jurídico da União, não cria competência ou missões novas para a União, também não modifica as competências e missões definidas nos tratados (51.2 CDFUE y 6.3 TUE). ${ }^{25}$ Isso significa que a positivação da Carta se encontra justaposta na distribuição de competências predeterminada nos tratados. Os direitos fundamentais da Carta não refletem por si mesmos, como é próprio da sua natureza, a forma de exercício do poder público, seus contornos e limites em relação aos cidadãos. Para conhecer a verdadeira eficácia e alcance dos direitos da Carta

\footnotetext{
${ }^{24}$ Cruz Villalón (2005, p. 185) criticou naquele momento que a introdução da Carta na Constituição europeia foi um processo de "juridificação" e constitucionalização muito mais aparente que real. Embora isso não obste o autor de conceder atualmente toda a notoriedade da existência de uma Carta de Direitos Fundamentais da União: "Em suma, a comunhão constitucional europeia encontra hoje uma peça básica de sua complexa estrutura em um documento não menos complexo, presidido por um título, embora mal compreensível: 'Carta dos direitos fundamentais da União Europeia'. Uma norma jurídica dotada da mais alta classificação no ordenamento jurídico da União." (CRUZ VILLALÓN, 2017).

${ }^{25}$ Conforme explicações da CDFUE, "Trata-se de mencionar explicitamente o que logicamente se infere do princípio da subsidiariedade e do fato de que a União possui apenas poderes de atribuição. Os direitos fundamentais garantidos na União só são eficazes no âmbito das competências que definem os Tratados. Por conseguinte, a obrigação das instituições da União, em conformidade com o segundo período do n. 1, de promover os princípios enunciados na Carta só pode ocorrer dentro dos limites das competências citadas."
} 
(isto é, qual o exercício de poder que limitam e em que medida), deve-se conhecer a repartição de competências trazida no texto dos tratados da União, do princípio da subsidiariedade e, inclusive, de eventual diálogo entre cortes constitucionais em sua versão de ultra vires review. ${ }^{26}$

Os principais obstáculos à eficácia da Carta, derivados das disposições gerais que regem a sua interpretação e aplicação, são os seguintes:

a) A incisiva distinção entre princípios e direitos. Os direitos fundamentais da Carta como limites ao exercício do poder público supranacional ficam comprometidos pela diferença imposta entre os princípios e direitos do Artigo 52.5 CDFUE, na versão de 2007. A diferença essencial, de acordo com a Carta, reside na questão de que princípios "devem ser observados", ao invés de "respeitados" (como assentado aos direitos); devem "ser aplicados mediante atos legislativos ou executivos", de modo que sua eficácia seja mediada. A eficácia dos princípios é reduzida "para os tribunais, somente quando se trata da interpretação ou revisão" dos atos da União, que os desenvolvem sem que possam operar como "direitos imediatos", mas como um incentivo para o desenvolvimento "de ações positivas das instituições da União ou das autoridades dos Estados-Membros." ${ }^{27} \mathrm{O}$ problema é que não se especifica com clareza, nem no texto e nem nas explicações que acompanham a Carta, quais disposições concretas são princípios e quais são direitos. Apenas alguns exemplos são apresentados para fins ilustrativos, observando também que, em algumas disposições, podem se encontrar ao mesmo tempo direitos e princípios e, em maior medida, que algumas disposições denominadas princípios podem ser direitos e vice-versa. ${ }^{28} \mathrm{~A}$ incerteza sobre os princípios, como a doutrina aponta, é prejudicial à eficácia de todos os direitos da Carta. ${ }^{29}$

\footnotetext{
${ }^{26}$ Referimo-nos à possibilidade de os tribunais constitucionais estaduais negarem a eficácia de uma disposição de direito europeu por transcender o âmbito de competência da União. Por um lado, apesar dos progressos na concretização do princípio da atribuição de competências no Tratado de Lisboa, a natureza finalista das competências da União continua a dificultar a compreensão do seu alcance, o que resulta no âmbito de aplicação dos direitos da Carta. Veja-se, a propósito, a publicação das decisões Melloni e Åkerberg, Editorial da European Constitutional Law Review, n. 9, p. 172 ss., 2012 : "Nevertheless, even if it is not certain where Union law begins and ends at this moment, it is certain that its scope will expand with the use that the Union legislature makes of its 'new' competences, especially in the field of home affairs and justice, domains in which fundamental rights are perhaps even more fundamental than in other domains." Como indicam os Tratados (art. 5.3 TUE) e a própria Carta, o âmbito das competências não exclusivas da União deve se situar no contexto dinâmico do princípio da subsidiariedade (LENAERTS, 2012, p. 377 ss.) com a complexidade que isso acarreta, dado o procedimento dos Protocolos anexados ao Tratado.

27 Veja explicações sobre o artigo 52.5 da Carta.

${ }^{28}$ Veja as explicações que acompanham a Carta, concretamente, a explicação sobre o artigo 52.5, cujo último parágrafo estipula: "[a] título ilustrativo, exemplos de princípios reconhecidos pela Carta incluem, entre outros, artigos 25, 26 e 37. Em certos casos, um artigo da Carta pode incluir elementos que derivam de um direito e um princípio, por exemplo, os artigos 23, 33 e 34." (HOFMANN; MIHAESCU, 2013, p. 73-101). Eles expressam a complexidade em torno do direito a uma boa administração, onde um terceiro elemento em disputa aparece: os princípios gerais do direito da União e a relação não hierárquica entre direitos, princípios e princípios gerais. Para LENAERTS (2012, p. 402): "[...] the scope of application of the Charter and that of general principles of EU law should overlap. A dual regime should be avoided, since it would give rise to arbitrary divergences as to the actual quality and potency of those rights."

${ }^{29}$ Krommendijk (2015, p. 321-356) e Prechal (2004, p. 177 ss.). Assim como explica Cruz Villalón (2013) nas conclusões do caso $A M S$, ap. 44: "Apenas é necessário começar por avisar como, na arquitetura da Carta, a categoria geral para a
} 
b) O artigo 51.1 da Carta tem duas facetas problemáticas. Por um lado, "as disposições da presente Carta são dirigidas às instituições, órgãos e organismos da União, respeitado o princípio da subsidiariedade, bem como aos estados-membros unicamente quando apliquem o Direito da União." (grifo nosso). A Carta limita o poder público das instituições da União, mas também dos Estados, quando eles atuam como meros "agentes da União". Nessa afirmação se apresenta uma dupla funcionalidade da Carta (CRUZ VILLALÓN, 2017, p. 87), que vincula ao mesmo tempo as instituições da União e aos Estados membros. É aqui que a cláusula do princípio da atribuição de competência apresenta sua força. A CDFUE, com "o mesmo valor jurídico dos Tratados (art. 6.1 TUE)", implica o mesmo compromisso aos Estados que o direito originário: limita e obriga suas atuações no interior da distribuição de competências entre a União e estados membros.

Os problemas relativos à capacidade da Carta para limitar o poder público se concentram precisamente no espaço em que são os poderes públicos dos Estados que atuam na aplicação do Direito. É aqui que devemos determinar se o fazem a partir da base legal dos tratados ou de suas próprias constituições. No primeiro caso, os limites à atuação do poder serão determinados pelo conteúdo dos direitos da Carta. No segundo caso, pelo conteúdo dos direitos fundamentais da Constituição do Estado, sendo que esse conteúdo pode não coincidir com o da Carta. ${ }^{30}$ Portanto, é essencial definir o quadro de competências da União e dos Estados antes de conceder um tipo ou outro de eficácia à Carta.

Por outro lado, o artigo 51.1 da Carta mostra um posterior problema de omissão, a saber, o da eficácia horizontal da Carta. Essa é uma omissão grave, tendo em conta a dimensão econômica do processo de integração europeia.

$\mathrm{Na}$ realidade, essas duas facetas, sua dupla funcionalidade e sua eficácia horizontal, possuem uma mesma origem, conforme veremos a seguir.

qual escolheu em sua própria denominação, os 'direitos fundamentais', em relação aos seus conteúdos deve ser previsível. Em outras palavras, nenhum conteúdo da Carta, em suas determinações substantivas, deve ser retirado da categoria de 'direito fundamental'. Convém advertir, e isso pode parecer menos obvio, que a circunstância de que um determinado conteúdo substantivo da Carta apareça, em algum outro lugar dela, qualificado como 'direito', não é ele descartado como um candidato à categoria 'princípio', no sentido do n. 5, artigo 52."

30 Veja-se Acórdãos do Tribunal de Justiça da União Europeia de 26 de junho de 1997, C-368/95, caso Familiapress; de 12 de junho de 2003, C-112/00, caso Schmidberger; de 11 de dezembro de 2007, C-438/05, caso Viking Line. Essa colisão é chamada pela doutrina europeia de derogation situation (LENAERTS, 2012, p. 383). A doutrina se encontra dividida entre duas perspectivas basilares (EDITORIAL EU CONST, 2013, p. 170): a perspectiva universalista, que prega a unificação de valores compartilhados através do procedimento jurisdicional (CARTABIA, 2009, p. 19; JACOBS, 2001, p. 331; PERNICE, 2015, p. 541-562). Cruz Villalón (2017, p. 90) e, portanto, a necessidade de que o conteúdo dos direitos da Carta coincida com o das Constituições estaduais através de garantias mínimas; e a historicista ou particularista, que proclama a diferença de efetividade e alcance do conteúdo dos direitos em diferentes níveis de proteção multinível de acordo com as escolhas sociais particulares de cada Estado (veja-se as conclusões do Advogado Geral Bott 2 de outubro de 2012, caso Melloni, C399/11, parágrafo 109). 


\subsection{0 artigo 51.1 e os diferentes níveis de proteção}

A jurisprudência do TJUE sobre o artigo 51.1 da Carta tem sido problemática. As contrariedades têm um núcleo claro: a colisão entre o nível de garantias da Carta e das constituições. Tal como o Tribunal de Justiça da União Europeia salientou no célebre caso Melloni, ${ }^{31}$ se se autoriza de forma geral que

um Estado-Membro aplique a norma de proteção dos direitos fundamentais garantida pela sua constituição, quando for mais elevada do que a norma derivada da Carta $[\ldots]$, se prejudicaria o princípio do primado do direito da União, dado que permitiria que um Estado-Membro colocasse obstáculos à aplicação de atos do direito da União plenamente em conformidade com a Carta, quando não respeitaram os direitos fundamentais garantidos pela Constituição desse Estado.

O nível de garantias constitucionais não é aplicável, nos termos do artigo 51.1, quando os Estados aplicam o direito da União. Por isso, é indispensável determinar em que casos isso ocorre, pois, por aplicação do Direito da União, deve-se entender tanto o momento em que os poderes públicos atuam como meros agentes de aplicação, como o momento em que incorporam a normativa comunitária, adotando normas internas exigidas pelo direito europeu (DE WITTE, 1999, p. 859).

No mesmo dia em que foi publicado o caso Melloni, o TJ decidiu o caso Åkerberg Fransson, ${ }^{32}$ esclarecendo essa ideia:

numa situação em que a ação dos Estados-Membros não é inteiramente determinada pelo Direito da União, as autoridades e os tribunais nacionais continuam habilitados para aplicar normas nacionais de proteção dos direitos fundamentais, desde que essa aplicação não afete o nível de proteção previsto na Carta, segundo sua interpretação pelo Tribunal de Justiça, nem à primazia, à unidade e à eficácia do direito da União.

Ou seja, quando o direito europeu atua com força "uniformizadora" e ocupa todo o espaço normativo, o nível de garantia dos direitos será exclusivamente o da Carta, que, se fosse inferior ao

\footnotetext{
${ }_{31}$ Acórdão do Tribunal de Justiça de 26 de fevereiro de 2013, Melloni, C-399/11, n. 58.

32 Nuance que claramente terá um caráter pacificador em relação ao caráter vinculante da "ordem europeia de detenção e entrega", que requeria uma clara orientação uniforme pelas várias decisões judiciais nacionais em que se declaravam as dúvidas constitucionais suscitadas pela "harmonização" da decisão paradigma de 2002, de âmbito penal e suas contradições com os princípios de igualdade e legalidade penal. A esse respeito, podem ser consultadas as conclusões do Advogado-geral Dámason Ruiz-Jarabo Colomer de 12 de Setembro de 2006, Leden van de Ministerraad, C 303/05, pontos 4 a 8: "A solução deste dilema exige enfrentar, sem hesitação, o papel dos direitos fundamentais num setor tão sensível como o da cooperação policial e judiciária em matéria criminal, após a proclamação da Carta dos Direitos Fundamentais da União Europeia. $\bigcirc$ desafio não parece insignificante, pois em alguns Estados-Membros a transposição da decisão paradigma ficou fora de jogo por violar garantias cidadãs." E as decisões dos tribunais europeus como: Trybunat Konstytucyjny (Tribunal Constitucional da Polônia), Acórdão de 27 de abril de 2005 (P 1/05). Bundes verfassungsgericht alemão (Tribunal Constitucional Federal), Acórdão de 18 de julho de 2005, 2 BvR 2236/04. Acórdão do Areios Pagos (Tribunal de Justiça grego) de 20 de dezembro de 2005 (Processo 2483/2005). Supremo Tribunal de Chipre, Acórdão de 7 de novembro de 2005 (Processo 294/2005). Ústavní Soud (Tribunal Constitucional Checo), Acórdão de 3 de maio de 2006 (Processo 66/04).
} 
das constituições nacionais, se aplicaria prioritariamente. Se, em contrapartida, o direito europeu permitisse uma margem de discricionariedade aos Estados para a sua aplicação, então estes poderiam impor o nível de garantias mais elevado das suas constituições (CARMONA CONTRERAS, 2016, p. 20 ss.; SARMIENTO, 2013, p. 1267-1304).

Essa dupla nuance levou a que, na minha opinião, o debate jurisdicional sobre a eficácia da Carta se desenvolvesse em torno da margem de discricionariedade deixada aos Estados para a transposição de diretivas europeias (ou de decisões modelos adotados em matéria penal antes da entrada em vigor do Tratado de Lisboa); esse será o contexto essencial em que se desenvolverá o debate sobre a eficácia da Carta e a sua aplicação. Ele conduzirá à questão da limitação do poder própria das cartas de direitos, da sua dimensão político constitucional (pelo seu caráter legitimador do direito) -, numa questão jurídico-técnica sobre a precisão, clareza e incondicionalidade dos termos das diretivas e do direito derivado em geral. Ou seja, a Carta passará a ser utilizada pela jurisdição europeia e nacional como "parâmetro de interpretação" das diretivas (AGUILAR CALAHORRO, 2018, p. 973-1011).

\subsection{A mera eficácia hermenêutica da Carta com relação às diretivas}

A jurisprudência do TJUE sobre o artigo 51.1 da Carta leva a pensar que a eficácia da Carta acaba por depender do direito derivado através do qual se desenvolve. E essa conclusão chega mesmo a tornar irrelevante a questão de saber se, em termos de competência, o conflito em que se aplicam os direitos da Carta se enquadra no âmbito da competência europeu ou estatal. Conforme assinalado pelo TJ no Acórdão Julián Hernández (GISBERT, 2017, p. 333-359), "o simples fato de uma medida nacional estar relacionada com o âmbito em que a União dispõe de competências, não pode integrá-la no âmbito de aplicação do direito da União e, por conseguinte, dar origem à aplicabilidade da Carta." 33

Além disso, salientamos que a aplicação da Carta pode ser efetuada mesmo no quadro de competência exclusiva dos Estados-Membros. Assim, com base na doutrina ERT, ${ }^{34}$ por vezes, qualquer medida nacional que implique "uma exceção a uma das quatro liberdades fundamentais garantidas pelo Tratado, deveria ser incluída no âmbito de aplicação do direito europeu"35, até mesmo em situações que claramente se encontram, "a priori, fora do âmbito de competências da União." ${ }^{36}$

\footnotetext{
${ }_{33}$ Acordão do Tribunal de Justiça de 10 de julho de 2014, Julián Hernández, C-198/13. Igualmente Acórdãos do Tribunal de Justiça de 15 de setembro de 2011, Gueye e Salmerón Sánchez, C483/09 e C1/10, p. 55, 69 e 70, e Acordão do Tribunal de Justiça de 27 de novembro de 2012, Pringle, C370/12, p. 104, 105, 180 e 181.

34 Acordão do Tribunal de Justica de 18 de julho de 1999, ERT, C-260/89. Acordão do Tribunal de Justiça de 30 de abril de 2014, Pfleger, C-390/12.

${ }_{35}$ Repetimos que se trata da chamada derogation situation, em que se concentram críticas da doutrina do TJUE.

36 Situações que, a priori, são competência dos Estados-membros, podem estar "intrinsicamente [relacionadas] com a liberdade de circulação de um cidadão da União, que se opõe ao direito de entrada e residência que lhes seja recusada aos nacionais [de um país estrangeiro] no Estado-Membro em que reside o cidadão, [e isto] para não prejudicar esta liberdade."
} 
O efeito útil dos Tratados poderia permitir a aplicação da Carta inclusive a situações que ficam fora das competências da União.

Essa situação torna complicada a determinação sobre quando os Estados aplicam ou não o direito europeu e quando os direitos da Carta têm ou não eficácia num caso concreto; assim, chegouse a um case by case, no qual toda a questão se reconduz à margem de discricionariedade deixada pela diretiva de desenvolvimento do direito aos Estados e na sua transposição.

Da jurisprudência do TJUE pode traçar-se um possível teste de aplicabilidade da Carta, que encerra essa conclusão e que podemos resumir nas seguintes afirmações:

Para que a Carta seja diretamente aplicável e se desloque à aplicação do direito estatal:

a) O ato nacional de execução ou de aplicação deve emanar diretamente de uma obrigação europeia. ${ }^{37}$

b) Deve existir um "vínculo de conexão" entre um ato do direito da União e a medida nacional em questão. Este vínculo de conexão não é qualquer vínculo, mas aquele em que há um grau superior de proximidade das matérias consideradas ou de incidências indiretas de uma matéria na outra. Ou seja, o ato nacional deve ser desenvolvimento diretamente e "exigido" pela norma europeia. ${ }^{38}$

c) Deve existir identidade na finalidade perseguida pelo ato nacional e pela norma europeia: a medida europeia deve ter por finalidade regular a matéria desse caso concreto. Embora a UE tenha competência nessa matéria, deve haver também uma vontade clara por parte das instituições de regular esse caso concreto; além disso, a medida nacional deve ter por objetivo aplicar essa norma europeia concreta.

A diferença entre a natureza de princípios e direitos da Carta e as indicações do caso Julián Hernández alertam que, para que o juiz aplique o "Direito da União", no sentido do artigo 51.1 do CDFUE, deve haver um desenvolvimento legislativo, deve ter-se pensado previamente no processo nacional, não tanto a eficácia de um direito fundamental da Carta, mas sim a aplicação do direito derivado que desenvolve uma disposição da Carta. ${ }^{39}$

Acordão do Tribunal de Justiça de 5 de junho de 2018, Coman, C- 673/16. Acordão do Tribunal de Justiça de 13 de setembro de 2014, Rendón Marín, C- 165/14. Acordão do Tribunal de Justiça de 21 de dezembro de 2016, AGET Iraklis, C-201/15.

37 Acordão do Tribunal de Justiça de 6 de março de 2014, Siragusa, C-206/13. Acordão do Tribunal de Justiça de 13 de junho de 2017, Florescu, C-258/14. Acordão do Tribunal de Justiça Julián Hernández, cit., p. 37: "para determinar se uma normativa nacional guarda relação com a aplicação do Direito da União, na interpretação do artigo 51 da Carta, deve verificar-se, se o objetivo da legislação nacional em causa, é aplicar uma disposição do direito da União, a natureza dessa legislação, se a ela possui objetivos diferentes dos previstos no direito da União, ainda que possa afetá-lo indiretamente, se existe uma normativa específica de direito da União na matéria, ou que a ela possa afetar."

38 Acordão do Tribunal de Justiça Julián Hernández, cit., p. 37.

39 Acordão do Tribunal de Justiça de 10 de julho de 2014, Julián Hernández, C-198/13, e de 27 de março de 2014, Torralbo Marcos, C- 265/13. Relacionam-se com o Acordão do Tribunal de Justiça de 8 de abril de 2014, Direitos Digitais da Irlanda, C-293/12, com Acordão do Tribunal de Justiça de 13 de maio de 2014, Google Espanha e Google, C-131/12. 
As orientações desenvolvidas no teste de aplicação levam-nos a pensar que existe um âmbito próprio para a implantação efetiva do artigo 51.1 do CDFUE. O âmbito natural do controle da aplicação da Carta é o das diretivas. $\bigcirc$ momento em que o juiz nacional aprecia a aplicabilidade de disposições decorrentes de uma diretiva, é o momento em que o teste de aplicação é relevante, porque se concretiza aqui o princípio de atribuição de competências na análise por parte do juiz da margem de discricionariedade deixada aos Estados. É em torno das diretivas que o ato de execução e de aplicação pelo poder público pode salvar a exigência de uma ligação estreita de conexão, e onde se pode avaliar se um ato normativo europeu e um ato normativo nacional têm a mesma finalidade material.

O próprio Tribunal de Justiça continuou a desenvolver orientações para os juízes em torno da aplicação da Carta na seleção de disposições de uma diretiva para resolver um caso concreto. Vamos continuar com o teste.

d) A disposição da diretiva específica não deve permitir margem de apreciação ao Estado: ou seja, a diretiva impõe aos Estados uma obrigação específica (clara, precisa e incondicional) relativa à situação do processo principal. Além disso, a diretiva ou decisão paradigma deve procurar harmonizar as condições de execução, não deixando qualquer margem de apreciação, pois, em outras palavras, a ação dos Estados deve estar totalmente determinada pelo Direito da União. ${ }^{40}$

e) Mesmo que a diretiva permita uma certa margem de apreciação, o ato nacional não poderá prejudicar a primazia, a eficácia ou a unidade do direito europeu. ${ }^{41}$ Em outras palavras, a Carta também se aplica quando uma autoridade nacional exerce um poder discricionário que lhe foi conferido pela legislação da União. ${ }^{42}$

Em conclusão, é no momento da aplicação da diretiva europeia (ou decisão-paradigma ${ }^{43}$ ) que o juiz nacional deveria sentir-se no epicentro do art. 51.1 CDFUE, tal como explicado pelo TJUE. É o momento em que a atuação do poder público estatal se encontra imediatamente configurada como um agente europeu de aplicação ou implementação da norma europeia, diretamente vinculado pela norma europeia e limitado pelos direitos fundamentais da Carta.

\footnotetext{
${ }_{40}$ Acordão do Tribunal de Justiça de 26 de fevereiro, Melloni, C- 399/11. p. 62 e 63. E novamente, Acordão do Tribunal de Justiça Torralbo Marcos, cit., e Siragusa, cit.

${ }^{41}$ Acordão do Tribunal de Justiça Melloni, loc. cit.

42 Indicações da Comissão, Relatório de 2013 sobre a aplicação da CDFUE (2013/2078(INI). Acordão do Tribunal de Justiça de 13 de junho de 2017, Florescu e outros, C-258/14. E sentença do Tribunal de Justiça de 21 de dezembro de 2011, N.S. e outros, C-411/10

43 Acordão do Tribunal de Justiça de 16 de junho de 2005, Maria Pupino, C-105/03.
} 
Contudo, nesse âmbito, surgem as dúvidas próprias da configuração dessa fonte do direito europeu, da diretiva como transmissora de direitos aos cidadãos. ${ }^{44}$ Ao situar-se o núcleo da questão na maior ou menor discricionariedade deixada ao Estado para o desenvolvimento e execução do direito derivado europeu, la ratio decidendi se insere no clássico debate sobre a eficácia das diretivas (clareza, precisão e incondicionalidade, eficácia horizontal, efeitos de exclusão e relações triangulares), sendo o cerne da decisão o texto literal das diretivas e a Carta uma mera ferramenta interpretativa. $\bigcirc$ debate sobre a Carta reconduz, então, à doutrina geral sobre a sobre a eficácia direta das diretivas.

Limitar o poder da Carta de Direitos Fundamentais a este cenário diminui, sem dúvida, a sua eficácia. O menos importante, conforme observa o TJUE, é que se deduza de forma clara da CDFUE ou da jurisprudência um direito subjetivo concreto. Também não se pretende limitar o poder atribuído pelo direito europeu. $\bigcirc$ essencial, ao que parece, são as peculiaridades da discricionariedade deixada ao Estado na aplicação do direito europeu que desenvolve a Carta.

Em suma, conduzir o valor de aplicação da Carta ao debate sobre a eficácia direta das normas de execução, essencialmente, das diretivas, desfaz a própria ideia dos direitos num duplo sentido. Por um lado, como adverte a doutrina, a eficácia direta pode às vezes coincidir com a criação de direitos subjetivos, mas nem sempre é o caso (PRECHAL, 1995, p. 129). Veja por exemplo, a possibilidade de o direito europeu adquirir eficácia de exclusão, sem que se aplique qualquer direito substantivo. ${ }^{45}$ Por outro lado, e o que nos interessa agora, traçar um paralelismo entre a eficácia da Carta e a eficácia das diretivas reduz aquela às suas escassas possibilidades de eficácia vertical e as priva, em geral, de efeitos horizontais, quer dizer, da possibilidade de fazer valer o direito concedido pela Carta relativamente a outros particulares.

\subsection{Consequências para a eficácia da Carta}

De um modo geral, podemos apresentar algumas conclusões do exposto.

$\mathrm{O}$ artigo $6^{\circ}$ do Tratado da União Europeia confere à Carta o mesmo valor jurídico que os Tratados, isto é, autonomia, eficácia direta (onde existe um direito preciso e incondicional) e primazia. No entanto, vimos que o artigo 51.1 do CDFUE foi interpretado num sentido que limita a eficácia da Carta face aos poderes públicos dos Estados: a sua aplicação centra-se na maior ou menor

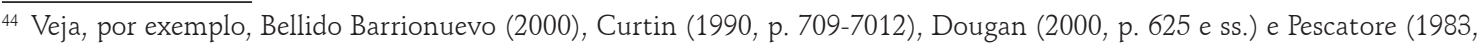
p. 155 ss.). Veja também as conclusões do Advogado-geral Léger de 11 de janeiro de 2000, sobre Linster, C-287/98, p. 30, que expõe sobre a eficácia direta das diretivas: "[...] que reflete em grande medida a repartição de competências entre os Estados-Membros e a Comunidade, o que incita a não instaurar como princípio a equiparação das Diretivas, atos de cooperação legislativa, com os regulamentos, regras privilegiadas no âmbito das atuações que são de competência exclusiva da Comunidade."

45 As conclusões do Advogado-geral Ruiz Jarabo, sobre Arcor, C-152,154/07: "Não obstante, os anos não conseguiram silenciar vozes a favor do reconhecimento do efeito direto horizontal como a do advogado-geral Lenz nas suas conclusões para o caso Faccini Dori, apoiando-se, por sua vez, nos argumentos apresentados anteriormente pelos advogados-gerais Van Gerven e Jacobs. Concede aos autores o sentimento de uma oportunidade perdida, apesar de o Tribunal de Justiça não ter hesitado em aplicar a sua doutrina quando a diretiva se repercute em direitos de particulares, alheios à relação vertical, surgindo assim a teoria das relações triangulares." Ver pontos 100 e 101.
} 
discricionariedade deixada ao Estado por suas diretivas de execução. Ademais, tem-se que os direitos parecem não ser atribuídos diretamente pela Carta, mas sim pela normativa de desenvolvimento.

Fazendo-se uma análise das explicações da Carta, pelo menos um quinto dos direitos encontram diretamente a sua verdadeira fonte em diretivas ou decisões paradigmas aprovadas anteriormente, ${ }^{46}$ e apenas é o caso dos direitos em que são especificados de forma explícita. Além disso, a alteração de 2007, referente ao artigo 52.2, que estabelece que

as disposições da presente Carta que contenham princípios podem ser aplicadas por atos legislativos e executivos adotados pelas instituições, órgãos e organismos da União, e por atos dos Estados-Membros que apliquem o Direito da União no exercício das respectivas competências. Só podem ser invocados perante um tribunal no que diz respeito à interpretação e ao controle da legalidade desses atos.

Como se pontua nas explicações da Carta, isso significa que "não dão lugar a direitos imediatos de ações positivas das instituições da União ou das autoridades dos Estados-Membros." Estas explicações acrescentam outros quatro direitos/princípios à lista anterior, que vê reduzida a sua possibilidade de invocação direta. ${ }^{47}$

Podemos afirmar que a eficácia da Carta requer, em um imenso número de casos, uma normativa de desenvolvimento para produzir eficácia direta e poder ser invocada pelos cidadãos. Isto é, da interpositio legislatoris ou da interpretação judicial, que só poderá utilizá-la como canon de controle desses atos.

Esse raciocínio não deixa de ser uma aplicação do drittwirkung a nível europeu. A eficácia dos direitos se realiza através da interpositio legislatoris da União, porém a fonte maioritária é a diretiva. O drittwirkung europeu traz novos problemas, vejamos:

a) Devemos recordar que os direitos que haviam sido desenvolvidos através de diretivas, que é o caso de pelo menos 14 dos direitos enunciados na Carta, não produzem eficácia direta entre particulares: nem sequer podem ser invocadas de forma mediata através de normativas de execução - ou de procedimentos processuais adequados em relação a particulares;

b) Devemos recordar o que isto significa para a teoria da subjetividade do Direito internacional (recordemos: a subjetividade depende da capacidade de fazer valer os direitos diretamente atribuídos pelo ordenamento internacional);

\footnotetext{
46 São os artigos: 3 (proibição de escravatura), 8 (proteção de dados), direito à não discriminação, 11 (liberdade de informação. Televisão) 17 (propriedade), 23 (igualdade entre mulheres e homens), 27 (informação na empresa), 30 (proteção em caso de despedimento, transferência ou insolvência), direito a condições de trabalho justas e equitativas, proibição do trabalho infantil, conciliação.

${ }^{47}$ A título de exemplo, princípios reconhecidos pela Carta incluem, entre outros, os artigos 25, 26 e 37 . Em certos casos, um artigo da Carta pode incluir elementos decorrentes de um direito e de um princípio, como no caso dos artigos 23,33 e 34 .
} 
c) Além disso, no sistema constitucional, a ideia de dritwirkung se estrutura através da eficácia mediata. Em contrapartida, no sistema europeu, a eficácia horizontal se constrói sob uma perspectiva um tanto quanto diferente: o conceito de efeitos indiretos ou de relações triangulares. E isso tem consequências imediatas na eficácia da Carta: as pretensões subjetivas fundadas nos direitos da Carta ficam reduzidas à inaplicação ou interpretação conforme das disposições nacionais.

Sendo assim, poderíamos dizer que a jurisprudência do TJCE e as disposições de aplicação da Carta poderiam ter suprimido o conceito de cidadão como sujeito do direito europeu - no que funda uma inovação na natureza da União Europeia.

Não admira, portanto, que, dez anos após a sua entrada em vigor, a jurisprudência do TJUE tenha dado um giro copernicano recentemente.

\section{Evolução da eficácia dos direitos sociais da Carta: eficácia directa e horizontal}

Em novembro de 2018, a jurisprudência do TJUE confirmou essas suspeitas. A Carta tinha sido relegada a ser "figurante" frente aos Tratados. Além disso, parecia que, em vez de situar os cidadãos no lugar que lhes pertencia - como sujeitos do direito europeu -, os recolocava numa posição já superada inclusive pelo iuspublicismo.

Dessa maneira, o Tribunal Europeu tem estado plenamente consciente do protagonismo que as diretivas adquiriram como "intermediárias" da eficácia da Carta. Por isso, começou a abrir alternativas corajosas que incluem o reconhecimento da eficácia direta horizontal dos direitos sociais da Carta, exemplo disso, é o direito às férias remuneradas.

Por que essa mudança? Porque fica clara a centralidade das diretivas no desenvolvimento legislativo dos direitos da Carta e os problemas que se coloca para a sua eficácia direta, especialmente horizontal (CRUZ VILLALÓN, 2017). Como é que isso aconteceu? Através de um desenvolvimento continuado da jurisprudência, que combina a eficácia jurídica dos princípios gerais do direito europeu com a eficácia da Carta.

Esta conclusão final, pode ser claramente observada à luz da evolução da jurisprudência do TJUE da última década.

Observa-se, por exemplo, o caso Maribel Dominguez:48 Esta questão, como sabemos, dizia respeito ao direito à férias remuneradas entre uma trabalhadora temporariamente incapacitada e o seu empregador. O TJUE reconheceu que o direito de cada trabalhador a férias anuais remuneradas deve ser considerado um princípio de direito social da União de especial importância, ao qual não podem ser estabelecidas exceções, e cuja aplicação pelas autoridades nacionais competentes só pode

\footnotetext{
$\overline{48}$ Acordão do Tribunal de Justiça de 24 de janeiro de 2012, C282/10, Maribel Domínguez, n. 16 e 17.
} 
ser efetuada dentro dos limites expressamente estabelecidos pela Diretiva 93/104/CE do Conselho. Ou seja, a eficácia deste princípio geral de direito social depende da possibilidade da diretiva poder ser invocada numa relação horizontal. Assim, no caso Maribel Domínguez, o resultado final da invocação do direito fundamental foi forçar a "interpretação conforme" e a indenização ao particular, reconhecendo a responsabilidade do Estado no descumprimento da diretiva. Como se observa nesse exemplo clássico, a doutrina do TJ concentrou-se no cumprimento das obrigações comunitárias por parte dos Estados.

No entanto, e aqui a evolução, em novembro de 2018 no caso Bauer o TJUE mudou radicalmente seu entendimento sobre o embasamento do mesmo direito:

[...] nem o artigo 7 da Diretiva 93/104 e nem o artigo 7 da Diretiva 2003/88 estabeleceram, por si mesmos, o direito a férias anuais remuneradas, sendo que a origem desse direito se encontra em diversos instrumentos internacionais e, como princípio fundamental de direito social da União, tem carácter imperativo [...] Desse modo, o direito a um período de férias anuais remuneradas que artigo 31, n. 2, da Carta reconhece a todo trabalhador, se caracteriza por sua existência, que foi estabelecida de forma imperativa e ao mesmo tempo incondicional, na medida em que efetivamente, não necessita ser concretizado por disposições do direito da União ou do direito nacional [...] Daqui resulta que essa disposição é suficiente por si só para conferir aos trabalhadores um direito que pode ser invocado como tal num litígio com a sua entidade patronal, relativo a uma situação abrangida pelo direito da União e compreendida no âmbito de aplicação da Carta. ${ }^{49}$

Poderíamos pensar que foi a entrada em vigor da Carta que conduziu a essa mudança. Mas não. O processo foi longo. No recorrente "diálogo entre Advogados Gerais" foram consideradas, ao longo do tempo, diversas opções para contornar a problemática da ineficácia horizontal das diretivas nos casos em que se tratavam de direitos subjetivos para os particulares. Ao longo dos anos, foram consideradas quatro alternativas para contornar os problemas de eficácia direta da Carta, especialmente no caso de relações entre particulares. Quatro alternativas que se desenvolveram, não consecutivamente, no tempo. ${ }^{50}$

Em primeiro lugar, conferir eficácia horizontal às diretivas. Opção, continuamente proposta pelos Advogados-Gerais perante o TJUE. Mas não houve expressamente nenhum passo atrás desde o caso Marshall. ${ }^{51}$

\footnotetext{
49 Acordão do Tribunal de Justiça de 6 de novembro de 2018, C569/16 e C570/16, Maria Elisabeth Bauer (C569/16).

${ }^{50}$ Ver as conclusões da Advogada-geral Verica Trstenjak, apresentadas em 8 de setembro de 2011, no Processo C282/10, Maribel Dominguez.

51 Veja-se o Acordão do Tribunal de Justiça de 2 de agosto de 1993, Marshall, sobre C-271/91. Citam-se as palavras do Advogado-geral Ruiz Jarabo sobre as conclusões no caso Arcor, de 1 de abril de 2008, C-152,154/07: "Não obstante, os anos não conseguiram silenciar vozes a favor do reconhecimento do efeito direto horizontal, a exemplo do Advogado-geral Lenz, nas suas conclusões para o Processo Faccini Dori, apoiando-se, por sua vez, nos argumentos apresentados anteriormente pelos advogados-gerais Van Gerven e Jacobs. Concede aos autores o sentimento de uma oportunidade perdida, apesar de o Tribunal de Justiça não ter hesitado em aplicar a sua doutrina quando a diretiva se repercute em direitos de particulares, alheios à relação vertical, surgindo assim a teoria das relações triangulares." Ver pontos 100 e 101.
} 
Em segundo lugar, forçou-se a equiparação dos direitos fundamentais ao regime jurídico das liberdades fundamentais. Desde a sua origem (especialmente desde a STJUE Defrenne ${ }^{52}$ ), têm sido constantes as referências jurisprudenciais à eficácia direta horizontal das liberdades fundamentais da União. Acórdãos que poderiam ser agrupados em torno dos processos Bosman, ${ }^{53}$ Schmidberger ${ }^{54}$ ou Comissión contra Francia ${ }^{55}$ e das restrições à liberdade de circulação. Todos estes processos se baseiam fundamentalmente na argumentação de que os atos dos particulares podem pôr em perigo os objetivos das disposições relativas à livre circulação, acabando por admitir a invocação das liberdades fundamentais da União face à sua restrição por parte de outros particulares. ${ }^{56}$ Permite-se, assim, a conversão do princípio da não discriminação num princípio geral de direito europeu, ainda que tenha sido desenvolvido por uma diretiva, para lhe conferir eficácia direta horizontal. No entanto, a chave para essas questões não se centra tanto na proteção iusfundamental de um direito subjetivo como tal, mas em contornar um eventual desequilíbrio estrutural entre as partes ou a possibilidade de quebrar o princípio da livre concorrência. ${ }^{57}$

A terceira alternativa para ultrapassar os problemas de ineficácia horizontal das diretivas tem sido a conversão do direito desenvolvido numa diretiva em princípio geral do direito europeu. Pode-se situar sua origem no caso Mangold. ${ }^{58}$ Nele, o TJUE converteu o princípio de não discriminação por razão de idade, de diretiva em princípio geral de Direito comunitário. ${ }^{59}$

A última alternativa é apresentada quatro anos mais tarde, no caso Kücükdeveci, pelo advogado-geral BOT. Ele questionava: por que não fundamentar a eficácia direta horizontal do princípio da não discriminação (com base na idade) na própria Carta e não num princípio geral de

\footnotetext{
$\overline{52}$ Acordão do Tribunal de Justiça de 8 de abril de 1976, Defrenne, Processo 43/75.

${ }^{53}$ Acordão do Tribunal de Justiça de 15 de dezembro de 1995, Bosman, Processo C-415/93.

54 Acordão do Tribunal de Justiça de 12 de junho de 2003, Schmidberger, Processo C-112/00.

55 Acordão do Tribunal de Justiça de 9 de dezembro de 1997, Comissión de las Comunidades Europeas contra República Francesa, Processo C-265/95.

${ }^{56}$ Acordão do Tribunal de Justiça de 6 de junho de 2000, Angonese, Processo C-281/98, equipara, por exemplo, os efeitos do princípio da não discriminação no trabalho com as restrições às liberdades fundamentais, permitindo a sua invocação em litígios entre particulares. Mais recentemente, salienta-se as Conclusões da Advogada-Geral Sharpston apresentadas em 13 de julho de 2016, no Processo C-188/15, Bougnaoui, n. 62. Ou as apresentadas pela mesma Advogada-Geral no Processo Farrel, em 22 de junho de 2017, Processo C 413/15.

57 Recentemente, o Tribunal de Justiça das Comunidades Europeias tem observado o princípio da não discriminação de um ponto de vista alheio ao mercado interno, com "auténtica iusfundamentalidad". Veja o Acórdão do Tribunal de Justiça (Gran sala) de 17 de abril de 2018, Egenberger, Processo C-414/16. Nele, o princípio da não discriminação com base em motivos ideológicos é um princípio do direito europeu em um processo entre uma associação alemã e uma cidadã do mesmo país.

${ }^{58}$ Acordão do Tribunal de Justiça de 22 de novembro de 2005, Mangold, C-144/05: "Apesar de a Carta ainda não estar em vigor, a linguagem é completamente consubstancial: Portanto, o princípio da não discriminação em razão da idade deve ser considerado um princípio geral do direito comunitário. Quando uma legislação nacional está abrangida pelo seu âmbito de aplicação, como acontece com [...] a Lei de 2002, na sua qualidade de medida de aplicação da Diretiva 1999/70, o Tribunal de Justiça, que tem conhecimento de um processo apresentado a título prejudicial, deve fornecer todos os elementos de interpretação necessários para a apreciação, por parte do tribunal nacional, da conformidade dessa legislação com esse princípio." Igualmente Acórdão do Tribunal de Justiça de 12 de dezembro de 2002, Rodriguez Caballero, C 442/00.

${ }^{59}$ No caso Mangold, cit. dispõe-se: "Por conseguinte, o respeito do princípio geral da igualdade de tratamento, em especial em razão da idade, não pode, por si só, depender do termo do prazo concedido aos Estados-Membros para adaptarem a sua legislação nacional a uma diretiva que estabeleça um quadro geral de luta contra a discriminação em razão da idade, nomeadamente no que se refere à organização de vias de recurso adequadas, ao ónus da prova, à proteção contra represálias, ao diálogo social, às ações positivas e a outras medidas específicas de aplicação da referida diretiva”, n. 76 do relatório.
} 
direito ${ }^{60}$ A contribuição do Advogado-geral apontava para a iminente entrada em vigor da Carta e para a necessidade de se superar os problemas decorrentes da sua ineficácia entre particulares. ${ }^{61}$ Apesar da proposta clara, o TJUE voltou a resolver a questão da ineficácia horizontal dos direitos previstos nas diretivas através da técnica da eficácia indireta (drittwirkung). ${ }^{62}$ No entanto, pareceu ter-se apontado uma nova e recente etapa.

Em novembro de 2018, o TJUE reconheceu, sem rodeios, que a Carta tem "o mesmo valor jurídico que os tratados". O "último" revés foi representado no caso Association de médiation Sociale $(A M S) .^{63}$ A questão volta a ser se o direito à informação e à participação dos trabalhadores em uma empresa, quando seus conteúdos foram concretizados por uma diretiva, pode ser invocado nas relações entre particulares. ${ }^{64}$ Coloca-se então duas opções: primeira opção, refere que se poderia utilizar da disposição de concretização do direito (a diretiva) como se do próprio direito fundamental se tratasse (conferir eficácia horizontal à diretiva por se considerar parte da própria Carta). A segunda opção, pugna por se utilizar estas normas de "concretização essencial e imediata" da Carta como eficácia indireta. Por outras palavras, permitir a "invocação" da diretiva numa relação horizontal, embora daí não resulte o reconhecimento de um direito substantivo, mas o deslocamento da norma nacional contrária.

O TJUE voltou a reconhecer o princípio da responsabilidade do Estado pela violação da diretiva, fugindo da iusfundamentalidad da Carta: ${ }^{65}$ se o princípio necessita de ser concretizado por

${ }_{60}$ Conclusões do Advogado-geral Yves Bot apresentadas em 7 de julho de 2009, C 555/07, Processo Kücükdeveci: "Assim, em primeiro lugar, em relação à própria existência do princípio da não discriminação em razão da idade como princípio geral do direito comunitário, estou inclinado a pensar que o fato de o Tribunal de Justiça salientar que este princípio corresponde à evolução desse direito tal como se verifica, por um lado, da inclusão da idade como critério de discriminação proibido no artigo 13, n. 1, CE e, por outro lado, da consagração da proibição das discriminações com base na idade como um direito fundamental, como resulta do artigo 21, n. 1, da Carta dos Direitos Fundamentais da União Europeia. É verdade que o raciocínio do Tribunal de Justiça teria sido mais convincente se tivesse sido sustentado por esses elementos, para além apenas dos instrumentos internacionais e tradições constitucionais comuns dos Estados-Membros que, na sua maioria, não determinam qualquer princípio de proibição específica das discriminações em razão da idade", ponto 77 do relatório.

61 "Levando em consideração que o direito comunitário se imiscui cada vez mais nas relações entre particulares, a meu ver, o Tribunal de Justiça terá inevitavelmente de enfrentar outros casos que levantem a questão da invocabilidade, em litígios entre particulares, de diretivas que contribuem para garantir direitos fundamentais. Estes pressupostos irão provavelmente aumentar se a Carta dos Direitos Fundamentais da União Europeia adquirir força jurídica vinculativa no futuro, dado que alguns dos direitos fundamentais referidos na Carta figuram no acervo comunitário sob a forma de diretivas. Nesta perspectiva, em minha opinião, o Tribunal de Justiça deve desde já refletir sobre se a identificação de direitos que constituem direitos fundamentais, garantidos por diretivas, o permite estabelecer a invocabilidade dessas diretivas ou não em litígios entre particulares. $O$ presente processo oferece ao Tribunal de Justiça a possibilidade de dar a resposta que deseja dar a esta importante questão." Ibidem, ponto 90.

${ }^{62}$ No que se refere, em primeiro lugar, ao papel do juiz nacional quando deve resolver um litígio entre particulares em que se verifica que a legislação nacional controvertida é contrária ao Direito da União, o Tribunal de Justiça declarou que cabe aos tribunais nacionais assegurar a proteção jurídica decorrente das disposições do direito da União para os litigantes e garantir o pleno efeito [...] a obrigação dos Estados-Membros, derivada de uma diretiva, de alcançar o resultado que esta prevê, bem como o seu dever de tomar todas as medidas gerais ou especiais adequadas para assegurar o cumprimento dessa obrigação, são impostas a todas as autoridades dos Estados-Membros, incluindo, no âmbito das suas competências, as autoridades judiciais. Acórdão do Tribunal de Justiça de 19 de janeiro de 2010 C 555/07, Kücükedeveci, p. 45-47.

${ }^{63}$ Conclusões do Advogado Geral Pedro Cruz Villalón apresentadas em 18 de julho de 2013, Processo C176/12, Association de Médiation Sociale.

64 Ibidem. Ponto 1.

65 Acordão do Tribunal de Justiça de 15 de janeiro de 2014, AMS, C-176/12, n. 47: "Note-se, a este respeito, que as circunstâncias do processo principal diferem das que conduziram ao Acórdão Kücükdeveci, acima referido, uma vez que o princípio da não 
diretiva, ele não é suficiente por si só para conferir um direito subjetivo invocável como tal numa relação horizontal. No entanto, aponta uma conclusão para o futuro: se o direito da Carta "se basta por si mesmo" para conceder direitos aos particulares, pode ser invocado sem necessidade de regras de concretização.

Essa última ideia será diretamente estabelecida de uma vez por todas no caso Egenberger:

A Diretiva 2000/78 não estabelece, por si só, o princípio da igualdade de tratamento em matérias trabalhistas, princípio que encontra a sua origem em diversos instrumentos internacionais e nas tradições constitucionais comuns aos Estados-Membros, [...] A proibição de qualquer discriminação baseada na religião ou nas convicções tem caráter imperativo como princípio geral do direito da União. Nos termos do artigo 21.1, da Carta, esta proibição é, por si só, suficiente para conferir aos particulares um direito que pode ser invocado como tal num litígio que os enfrente num domínio regido pelo direito da União. [...] Além disso, importa assinalar que, tal como o artigo 21 da Carta, o seu artigo 47, relativo ao direito à tutela judicial efetiva, é suficiente por si só e não é necessário que seja desenvolvido por outras regras do direito da União ou do direito nacional para conferir aos particulares um direito subjetivo. ${ }^{66}$

A conclusão é definitiva: os direitos da Carta que são por si só suficientes são direitos fundamentais que não dependem das normas de execução para a sua invocação. Eles são imperativos.

A imperatividade da Carta e a sua iusfundamentalidad chegam até ao fim, e devemos entender que se inaugurou uma nova época na eficácia da Carta, tal como observa o Advogado-Geral BOT: "O ponto de partida da reflexão que deve ser levada a cabo a este respeito baseia-se, em minha opinião, no fato de os direitos fundamentais reconhecidos pela Carta, em princípio, a fim de não se tornarem letra morta, devem ser protegidos, e, assim, poderem ser invocados diretamente perante os tribunais nacionais." 67

O TJUE assentou essa ideia. Além disso, concedeu uma nova significância ao direito às férias remuneradas, uma vez que o processo se refere ao direito de férias remuneradas anuais e sua concretização nas diretivas de 1993 e 2003 :

[...] nem o artigo 7 da Diretiva 93/104 e nem o artigo 7 da Diretiva 2003/88 estabeleceram, por si mesmos, o direito a férias anuais remuneradas, sendo que a origem desse direito se encontra em diversos instrumentos internacionais e, como princípio fundamental de direito social da União, tem carácter imperativo [...] Desse modo, o direito a um período de férias anuais remuneradas o que artigo 31 , n. 2, da Carta reconhece a todo trabalhador, se caracteriza por sua existência, que foi estabelecida de forma imperativa e ao mesmo tempo incondicional, na medida em que efetivamente, não necessita ser concretizado por disposições do direito da União ou do direito nacional, as quais apenas devem precisar a duração exata das férias anuais e, se for caso, certos requisitos para o exercício do direito. Daqui resulta que essa disposição é suficiente por si só para conferir aos trabalhadores

\footnotetext{
discriminação em razão da idade objeto do último caso, reconhecido pelo artigo 21.1, da Carta, é suficiente, por si só, para conferir aos particulares um direito subjetivo invocável como tal."

${ }^{66}$ Egenberger, cit. n. 75-78.

${ }^{67}$ Veja conclusões do advogado geral Yves Bot, apresentadas em 29 de maio de 2018, Processo 569/16-570/16, Bauer, n. 7
} 
um direito que pode ser invocado como tal num litígio com a sua entidade patronal, relativo a uma situação abrangida pelo direito da União e compreendida no âmbito de aplicação da Carta. ${ }^{68}$

\section{Conclusão}

Se há algo que distingue a natureza do direito europeu da natureza do direito internacional público, é a doutrina sobre a subjetividade jurídica. Os cidadãos europeus são sujeitos de direito europeu, pois podem invocar disposições europeias em defesa de pretensões subjetivas, de direitos, perante os Estados e perante outros particulares.

Neste sentido, as decisões basilares do TJUE Van Gend en Loss e Costa contra Enel, dos anos 1960, são devedoras do extenso debate doutrinal iuspublicista sobre as aproximações dualistas ao ordenamento internacional. Mas, especialmente da equiparação entre os pensamentos jurídicos por categorias materiais (direitos materiais) e por ações processuais. Da capacidade de invocar em sede jurisdicional disposições europeias deriva o direito substantivo, subjetivo.

A eficácia direta do direito europeu é, portanto, o elemento-chave que permite a consideração definitiva dos indivíduos como sujeitos do direito extra estatal. E essa é a ideia essencial do processo de integração política europeia.

No entanto, o passado ainda pesa muito. O oligopólio estatal dos sistemas internacionais e supraestatais impede a evolução dos sistemas jurídicos globais.

O regime jurídico da diretiva europeia foi, sem dúvida, condicionado pelas abordagens doutrinais sobre a subjetividade no Direito internacional. Por mais que queiramos reconduzir em termos constitucionais o debate em perfis de competência, a verdade é que a doutrina sobre a eficácia direta das diretivas (e a própria dinâmica funcionalista da União Europeia) não satisfaz a critérios de divisão de poder ou de repartição de competências, nem ao princípio da primazia.

A dinâmica europeia é mais visível como uma luta entre os cidadãos e os poderes materiais ou económicos. Entre o mercado interno e o dogma da livre concorrência frente à eficácia do "Direito" com maiúsculas na globalização econômica e financeira.

Não é de estranhar, nessa perspectiva, que os direitos econômicos e sociais tenham sofrido um déficit temporal na sua positivação internacional em relação a outros direitos. Também não é de estranhar que, a nível interno ou doméstico, este déficit seja observado da mesma forma.

Se o direito é um mecanismo de resolução de conflitos, ele deve se impor na esfera europeia e internacional. Tem de ser invocável e justificável. Vetar os cidadãos do acesso aos mecanismos de resolução de conflitos internacionais ou supranacionais parece um absurdo em meio à sociedade digital e à globalização financeira.

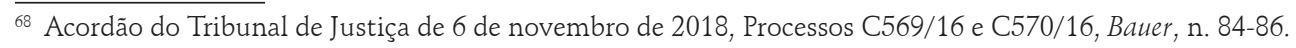


Por isso, a mais recente jurisprudência do TJUE retoma seu caminho "revolucionário". A invocação direta de direitos subjetivos perante instâncias extra estatais, sem intermediação dos poderes públicos estatais, representa, sem dúvida, a direção a ser seguida rumo ao constitucionalismo multinível. Quando se trata de conferir poder aos cidadãos na sociedade global, o constitucionalismo só conhece um mecanismo: a atribuição de soberania à cidadania (a ideia de que o poder nasce do povo) e a garantia da dignidade humana através da normatividade dos direitos humanos.

A evolução da eficácia dos direitos fundamentais na União Europeia reflete precisamente esta luta entre o empoderamento dos cidadãos e a tentativa de controlar a sua eficácia por parte dos Estados. Não é de estranhar que a Carta de Direitos tenha funcionado até certo momento às custas do seu desenvolvimento normativo através de diretivas, diretivas cujos destinatários imediatos eram os Estados, e só por sua violação, permitiam a exigência de responsabilidades perante os poderes públicos. No entanto, o direito supranacional, na era da globalização econômica, perde toda a virtualidade se impede a sua invocação face aos poderes econômicos que atuam sob a clássica aparência das pessoas jurídicas.

A recente jurisprudência do TJUE não só recupera a intocabilidade dos direitos subjetivos (fundamentais), mas também o faz em relações horizontais e, além disso, no quadro dos direitos de conteúdo socioeconômico.

Não se é sujeito de direitos se não se pode fazer valer em garantia de pretensões subjetivas. Não se é sujeito de direitos se uma parte essencial da globalização econômica é imune aos limites dos direitos fundamentais da Carta.

O caso Bauer, sem dúvida, representará um ponto de pressão para a evolução das doutrinas da eficácia mediata dos sistemas constitucionais internos e para repensar as relações entre a ação processual e o direito subjetivo. $O$ diálogo entre tribunais que envolve o sistema multinível de proteção dos direitos está também a transformar-se num diálogo entre categorias jurídicas. É importante salientar que a eficácia jurídica dos princípios gerais do direito europeu começa a ser combinada com a eficácia das cartas de direitos. Embora, como disse Cruz Villalón, não é um debate entre "direitos fundamentais vs. direitos humanos", mas sobre a eficácia do próprio Direito na esfera externa aos Estados. Âmbito onde se joga o verdadeiro jogo.

\section{REFERÊNCIAS}

AGUILAR CALAHORRO, Augusto. "La aplicación nacional de la Carta de derechos fundamentales de la UE: una simpleherramienta de interpretación de diretivas". Revista de Derecho Comunitario Europeo, n. 61, p. 973-1011, 2018.

AGUILAR CALAHORRO, Augusto. La Dimensión Constitucional del principio de primacía. Madrid: Thomson Reuters - Aranzadi, 2005. 
ALFARO, Jesús. "De nuevo sobre la Drittwirkung de los derechos fundamentales". Disponível em: https://almacendederecho.org/nuevo-la-drittwirkung-los-derechos-fundamentales. Acesso em: 14 jan. 2019.

ARANGIO-RUIZ, Gaetano. "Dualism revisited: international law and interindividual law". Rivista di Diritto Internazionale, [S. l.], n. 4, p. 909 ss., 2003.

ARANGIO-RUIZ, Gaetano. Gli enti soggetti dell'ordinamento Internazionale. Milano: Giuffrè, 1951. Disponível em: http://www.gaetanoarangioruiz.it/publications/gli-enti-soggetti-dellordinamento-rectius-del-diritto-internazionale/gli-enti-soggetti-dellordinamento-rectius-del-diritto-internazionale/. Acesso em: 18 fev. 2019.

BALAGUER CALLEJÓN, Francisco. "Soluciones apócrifas a problemas ficticios. Un comentario al dictamen del Consejo de Estado sobre el Tratado por el que se establece una constitución para Europa". La ley, [S. l.], n. 5, 2004.

BELADÍEZ, Margarita. "La eficacia de los derechos fundamentales entre particulares". Anuario de la Facultad de Derecho de la Universidad Autónoma de Madrid, [S. l.], n. 21, 2017.

BELLIDO BARRIONUEVO, María. La directiva comunitária. Madrid: Dykinson, 2000.

BOGDANDY, Armin von. "Notas sobre la ciencia del Derecho europeo: contexto, debates y perspectivas de desarrollo de la teoría general del Derecho de la Unión Europea desde el punto de vista alemán". Teoría y realidad constitucional, n. 5, p. 304-305, 2000.

CÁMARA VILLAR, Gregorio. "Los derechos fundamentales en el proceso histórico de construcción de la Unión Europea y su valor en el Tratado Constitucional". Revista de Derecho Constitucional Europeo, [S. l.], n. 4, 2005.

CARMONA CONTRERAS, Ana. "El espacio europeo de los derechos fundamentales: de la Carta a las constituciones nacionales". Revista Espanhola de Direito Constitucional, [S. l.], v. 107, p. 20 ss., 2016.

CARTABIA, Marta. "Europe and Rights: Taking Dialogue Seriously". European Constitutional Law Review, [S. l.], n. 5, p. 19, 2009.

CASSESE, Antonio. "Individuo (diritto internazionale)". Enciclopedia del diritto. Milano: Giuffrè, 1971.

CRUZ VILLALÓN, Pedro. "La Carta, o el convidado de piedra. (Aproximación a la Parte II del proyecto de Tratado/Constitución para Europa)". In: CLOSA MONTERIO, Carlos; Fernández Sola, Natividad (coord.). La Constitución de la Unión Europea. Madrid: Centro de Estudios Políticos y Constitucionales, 2005.

CRUZ VILLALÓN, Pedro. "La incidencia de la Carta (DFUE) en la confluencia de la eficacia horizontal de los derechos fundamentales y la ineficacia horizontal de las directivas: de Kükukdeveci a Dank Industri". Anuario de la Facultad de Derecho de la Universidad Autónoma de Madrid, [S. l.], n. 21, p. 101 ss., 2017.

CRUZ VILlalón, Pedro. Processo C176/12. Association de Médiation Sociale, 18 jul. 2013. 
CURTIN, Deirdre. "Directives: the effectiveness of judicial protection of individual rights". Common Market Law Review, [S. l.], n. 27, p. 709-7012, 1990.

DE WITTE, Bruno. "Direct effect, supremacy, and the nature of the legal order". In: CRAIG, Paul; DE BURCA, Gráinne. The evolution of EU Law. Oxford, New York: Oxford University Press, 1999.

DIEZ DE VELASCO, Manuel. Instituciones de Derecho Internacional Público. 13. ed. Madrid: Tecnos, 2002.

DÍEZ- PICAZO, Luis María. Constitucionalismo de la Unión Europea. Madrid: Civitas, 2002.

DOUGAN, Michael. "The Disguised vertical direct effect of directives?" The Cambridge Law Journal, [S. l.], n. 59, p. 625 ss., 2000.

FERRAJOLI, Luigi. Derecho y Garantías, la Ley del más Débil. Madrid, España: Ed. Trotta, 1999.

GISBERT, Rafael Bustos. "La aplicación de la CDFUE; un decálogo a partir de la jurisprudencia del Tribunal de Justicia de la Unión Europea". Teoría y Realidad Constitucional, [S. l.], n. 39, p. 333-359, 2017.

HÄBERLE, Peter. "El Estado Constitucional Europeo". Revista de Derecho Constitucional Europeo, [S. 1.], n. 11, p. 413 ss., 2009.

HOFMANN, Herwig C. H.; MIHAESCU, Bucura C. "The relation between the Charter's fundamental rights and the Unwritten General Principles of EU Law: Good administration as the Test Case". European Constitutional Law Review, [S. l.], n. 9, p. 73-101, 2013.

JACOBS, Francis. "Human rights in the European Union: the role of the Court of Justice". European Law Review, [S. l.], n. 26, p. 331, 2001.

KELSEN, Hans. Teoría pura del Derecho. 14. ed. Tradução: Roberto. J. Vernengo. México: UNAMA, 2005. p. 178 ss.

KROMMENDIJK, Jasper. "Principled silence or mere silence on principles? The role of the European Charters Principles in the case law of the Court of Justice". European Constitutional Law Review, [S. l.], n. 11, p. 321-356, 2015.

LENAERTS, Koen; CORTHAUT, Tim. "Of birds and hedges: the role of primacy in invoking norms of EU Law". European Law Review, [S. 1.], n. 31, p. 287 ss., 2006.

LENAERTS, Koen. "Exploring the limits of the EU Charter of fundamental rights". European Constitutional Law Review, n. 8, p. 377 ss., 2012.

MADURO, Poiares. Processo C-438/05, Viking Line. 23 maio 2007.

MASTROMARTINO, Fabrizio. "La soggettività degli individui nel diritto internazionale". Diritto e questioni pubbliche, [S. l.], n. 10, p. 416, 2010.

MODUGNO, Franco. Legge-ordinamento giuridico. Pluralitá degli ordenamenti. Milán: Giuffré, 1985.

O’CONNELL, Daniel Patrick. International law. Londra: Stevens and Sons, 1970. 
PERNICE, Ingolf. "Multilevel constitutionalism and the crisis of democracy in Europe". European Constitutional Law Review, [S. l.], n. 11, p. 541-562, 2015.

PESCATORE, Pierre. "La interpretación del derecho comunitario por el juez nacional". Revista de Instituciones Europeas, [S. l.], v. 23, n. 1, p. 7-32, 1996.

PESCATORE, Pierre. "The doctrine of 'direct effect': an infant disease of Community law". European Law Review, [S. l.], n. 8, p. 155 ss., 1983.

PRECHAL, Sacha. Directives in European Community law Study of Directives and Their Enforcement in National Courts. Oxford: Clarendom Press, 1995.

PRECHAL, Sacha. "Rights v. Principles, or how to remove fundamental rights from the jurisdiction of the courts". In: ZWAAN, Jaap W. de et al. (ed.). The European Union: An ongoing process of integration - Liber amicorum Alfred E. Kellerman. La Haya: TMC Asser Press, 2004. p. 177 ss.

QUADRI, Rolando. Diritto internazionale pubblico. Priulla: Palermo, 1949. p. 60.

QUADRI, Rolando. La sudditanza nel diritto internazionale. Padova: CEDAM, 1935. p. 58.

ROMANO, Santi. Corso di diritto internazionale. Padova: CEDAM, 1939. p. 60.

SARMIENTO, Daniel. "Who's afraid of the Charter? The Court of Justice, National Courts and the New Framework of Fundamental Rights protection in Europe". Common Market Law Review, v. 50, p. 1267-1304, 2013.

SPERDUTI, Giuseppe. L'individuo nel diritto Internazionale. Milano: Giuffrè, 1950.

WARD, Angela. Judicial Review and the Rights of Private Parties in EC Law. Oxford: Oxford University Press, 2000. p. 158. 
